\title{
Research on Business English Cross-cultural Communication Activity Context and Interactive Communication Mechanism
}

\author{
Danxia Liu ${ }^{1}$ \\ ${ }^{1}$ Hubei University of Science and Technology, \\ Xianning City, Hubei Province,437100 China
}

\begin{abstract}
In this paper, we conduct research on the business English cross-cultural communication activity context and interactive communication mechanism. Culture is the spirit of human creation achievements and composite material research, language is the best carrier of culture, is the core of the culture and values. Various forms of exchanges with the requirements of modern business people must have a strong business English pragmatic competence. Our method will help business managers to enhance their English ability under changeable circumstances which is meaningful.
\end{abstract}

Keywords: Business English; Cross-cultural and Interactive Communication; Novel Perspective.

\section{Introduction}

With the speeding up of economic globalization, as a member of WTO, the economic ties between China and the world is becoming more and more frequent. In order to adapt to the needs of international competition, China needs a large number of professional knowledge and familiar with the business world interdisciplinary talents have the ability to cross-cultural communication, the English teaching. Especially in business English teaching has brought unprecedented challenges. Therefore, colleges and universities business English teachers in the teaching should cultivate the students' ability of intercultural communication. Culture is the spirit of human creation achievements and composite material research, language is the best carrier of culture, is

\author{
Lijun Wang ${ }^{1, *}$ \\ ${ }^{1}$ Hubei University of Science and Technology, \\ Xianning City, Hubei Province,437100 China \\ Corresponding Author
}

the core of the culture and values. Man created language in labor, but also created the man himself, is the foundation of human from the animal kingdom of social language. Language and social culture closely intertwined, language is the product of the whole social culture and is the medium of culture. Due to the different cultural background, different cognitive, different values, different ways of thinking, behavior patterns, and so on have very big difference, and these differences affect the business activities of each link, and even decide the success or failure [1-2]. Our traditional business English teaching attaches importance to only make the students master all kinds of business knowledge combined with correct English, and neglect the cultivation of pragmatic competence in a cross-cultural environment. The correct language does not guarantee appropriate expression.

Therefore, in business English for communication, pragmatic failure is common. Various forms of exchanges with the requirements of modern business people must have a strong business English pragmatic competence, so in the business English teaching to cultivate and improve students' business English pragmatic competence in cross-cultural communication to all kinds of international business activities smoothly has extremely important practical significance. English is the language of the most frequently used in international trade, business English, this course aims to develop international trade talented person, should not only improve the students' English ability and to understand each link in 
international trade, therefore, business English teaching activities in addition to the necessary language knowledge teaching to the students' intercultural communication ability should also give full attention. With the rapid development of international economy, international business English more and more get people's attention, it increases not only the language application ability, or business areas of life and survival ability [3]. In foreign business activities, business English talents not only faced with their different political system, legal system and the economic environment, also will be affected by many language communication, nonverbal communication, social customs and practices, directly or indirectly affect the foreign business to carry out the influence of many factors.

In this paper, we research on the business English cross-cultural communication activity context and interactive communication mechanism. Intercultural communication is an important subject in recent years, as has been considerable attention to foreign language education field and the university business English major students' intercultural communication course is one of the important means to raise their ability. A lot of colleges and universities in China have opened a business English major or related business English course and cross-cultural communication. But the problem is that business English education in our country, the opening time of late, development time is shorter and the professional training mode and teaching method and content have defects which limits the students' cross-cultural ability raise [4]. Therefore, we conduct the related research in this paper. In the following sections, we will discuss the issues in detail.

\section{The Proposed Perspective and Methodology}

The Introduction of Cross-cultural influence people to the outside world views and understanding of things, and to properly identify and understand the different national culture characteristic of the function of verbal and nonverbal behavior, familiar with their habits in business activities of speech act and nonverbal behavior. To a specific scene, the words of the prophecy of one or more of the following may influence nonverbal behavior. The thinking mode of western culture pays attention to logic and analysis. While the thinking mode of the Oriental culture showed intuitive wholeness, which is also a leap in the characteristic of the traditional culture of thinking. The mistakes we may always make in the cross-cultural communication activities are listed as the follows. (1) Corporate hospitality. Reception of the customer is one of the indispensable work in international business, is the key to the business activities smoothly. How to use polite language gives customers make a good first influence, in addition to the instrument, appearance. Language is one of the most important factors. But due to the lack of cross-cultural awareness, many business people put their own values as a standard of business activities, inevitably cause pragmatic failure. (2) Business negotiation. In the process of negotiations, business people have to face different customers. The mode of their cultural background, negotiation, personality characteristics and values of differences are not allowed to ignore. Such as the United States people like to cut to the chase of negotiations, hate circuitous long conversation. While the Japanese tend to use euphemism, sometimes give each other a scratching their heads, etc. If don't understand etiquette habits in different countries, so in the commercial negotiations are likely to appear when social pragmatic failure, and sometimes even directly affect the results of the business negotiations. (3) Business letter. As the main business communication and the most widely application scope foreign-related documents, it plays a very important role in international trade. In the English business correspondence teaching, will be in strict accordance with the application of stylistic format and language characteristics to writing 
and translation, also note the difference between the applications of different occasions for different question tone. (4) Trademark language. A successful trademark translation should be able to attract target consumers, stimulate their wonderful imagination and purchasing desire.

Theory of intercultural communication is cross-cultural communication behavior and value concept of systematic, abstract and rational explanation. This theory Angle of view to compare successfully explain the communication process and result, accurately grasp the communicator, guide people to communicate more effectively. Intercultural communicative competence includes cross-cultural thinking ability. Business English pragmatic competence refers to the use of language in business communication and the ability of language comprehension. But pragmatic competence is not the same as grammar ability to master grammar knowledge doesn't necessarily have the ability to use language and understand the language.

\section{The Principles of Interactive} Communication. Interactive communication and context is, in fact, people usually say language environment, language and has a close connection between language environment and if there is no language environment, so the study of the theory of the language learning process will be completely. A large part of the researchers, said in a Chinese environment to learn English the biggest drawbacks is not creating the right English environment, so in recent years, people in the publicity of creating English environment. In business communication practice, when the results from the two cultural backgrounds and the final communication exists between closely related. Because the two sides from beginning to end is influenced by the culture of different, so in business negotiations is very easy to produce the problem such as coding errors but also more prone to conflict, serious will directly lead to the failure of the negotiations.

Business English of the main causes of the problems in cross-cultural communication, often in business communication both sides different in the way of communication. Chinese language and culture is a kind of high context culture, English is a kind of low context culture. Under the high context culture communication, tend to be more biased towards the indirectly expressing their own views. But low context culture more biased towards the direct expression. It is because of the differences between Chinese and western culture, may be the understanding of the context in communication that produce different forms, eventually produce inaccurate of cross-cultural communication. In the teaching, teachers should according to its status quo of students to design the corresponding communication activities, to present a more rich content, and set more reasonable business English curriculum in western culture, so as to effectively improve the students' ability of business English cross-cultural communication. Business English cross-cultural communication activities in context creation course, students get the chance to use English in practice, but it's important to note that in the process of cross-cultural communication activities which must pay attention to adhere to the principle of business English cross-cultural communication.

No matter what purpose is for cross-cultural communication activities, to communication each other respect is necessary to pay attention to one of the important problems, also can say this is keep harmony in cross-cultural communication interaction between elements. No matter which country, nation, people are eager to gain the respect of others, is not only a respect for itself, also eager to respect for their faith. In cross-cultural communication, if you can compare makes it clear that their own enough respect and friendly to each other, so the other person's response is bound to be is very positive, so that both sides of the communication will be easier. Usually, people will subconsciously when new to business English will be translated into English language. But it was also because of this that makes a lot of time translation result, 
combine English and thinking. Business communication is also done with verbal means and non-verbal means, in fact this is refers to the communication in the process of communication information is both or all parties through verbal means and non-verbal means to realize the normal delivery.

The Combination of the Context and Interactive Approach. In cross-cultural communication, under the situation of people on both sides of the communication both in language and culture, there is a big difference. In many cases, the cultural differences is far more difficult than the language difference, caused the interpretation in the communication barriers. Interpreters as the bridge of the communication on both sides and rightly its responsibility to remove the obstacles, improve the quality of the communication. Business English interpretation, as a special use English form of interpretation, belongs to the foreign business activities, both with business attributes, and involved in cross-cultural communication, natural counterpart interpreter proposes a bigger challenge. In cross-cultural communication, people can communicate is the premise of understanding of the language, the key is to understand cultural context carries more important information. Culture is not formed overnight, it needs long-term history. The formation of it will be affected by various factors such as geography, customs. Unavoidably exist differences between different cultures, therefore, mainly reflected in the people in a specific environment formed by the different world outlook, the outlook on life and way of thinking. In business English interpretation, often will meet for collision of cultures. Through pragmatic value be innovated development, business English pragmatics research attention gradually, and the market of cross-cultural communication ability of the urgent demand of business talents, we can see the necessity of business English pragmatic ability.
Business people's pragmatic competence is the main show is able to accurately understand the communication discourse contains words with different cultural backgrounds, habits of expression, polite formulas, titles, such as social and cultural language, and communicate with the will of the time which can use the target language in his own thoughts to natural expression.

Speech act is a social and cultural characteristic. Speech acts as a linguistic phenomenon commonly. Speech act is subject to certain social conditions. But it cannot exist without specific cultural and the judgment standard of each culture is different, the culture that is good, another culture might think is bad, but they are in their own cultural system has its rationality of the existence of, never can be understood as a kind of value standard is advanced, and the other a value standard lag behind. Different social conditions directly affect the performance of speech acts, to diversify the performance of the speech act, and result in the form of communication. The use of speech acts in different contexts and the performance of the relationship between languages a coordinated process.

The Summary and Suggestion. Language is the carrier of culture, is an inseparable part of culture. It reflects the culture, is influenced by culture. The practical applications and usages of international communication increasingly frequent, business English has become an increasingly important function. In cross-cultural communication, however, because do not understand the cultural background of the target language, do not pay attention to Chinese and western cultural differences and appear negative social phenomenon. Therefore, in today's various occasions business practice, improve the ability to cross-cultural communication is very necessary, and has important practical significance. With people of different value to different values orientation, in business activities, different countries have different customs and etiquette habits, with the common development 
of global productivity and the enhancement of human ideology and culture, the global mode of production, economic system and political system may converge in essence but cultural traditions, national characteristics will be permanent. Globalization pushes forward the development of the whole world, but also to business English teaching in China put forward higher request and the curriculum reform is imperative. We believe that the proposed approach will be effective.

\section{Conclusion}

This paper conducts analysis and research on the business English cross-cultural communication activity context and interactive communication mechanism. In many cases, the cultural differences is far more difficult than the language difference, caused the interpretation in the communication barriers. Interpreters are the bridge of the communication on both sides and rightly its responsibility to remove the obstacles which are becoming important recently. Unavoidably exist differences between different cultures, therefore, mainly reflected in the people in a specific environment formed by the different world outlook. The practical applications and usages of international communication increasingly frequent and business English has become an increasingly important function. We firmly believe that through the proposed perspective, our business English ability will be enhanced.

\section{References}

[1] Sacristán, M. V. (2014). Metaphor and esp: metaphor as a useful device for teaching 12 business English learners. Ibrica, 10.

[2] Ling Z. Innovation of Higher Vocational Professional Training System under University-Enterprise Cooperation-Case Study of the Business English Major Incubation Group of Suzhou Vocational Economic and Trade College[J]. Journal of Hubei Radio \& Television University, 2014.

[3] Wei W. Adaptive "Content" in CBI for Business English Teaching in Chinese Universities Based on Needs Analysis[J]. Journal of Beijing University of Chemical Technology, 2014.

[4] Xiang-jun H. On the Development of Critical Reading Ability of English Business Students through $\mathrm{CDA}[\mathrm{J}]$. Journal of Hunan University of Commerce, 2014. 